\title{
Sekundarna gospodarska središča v Ljubljani: analiza stanja in presoja načrtovanega razvoja
}

V prispevku predstavljamo sekundarna gospodarska središča v Ljubljani glede na stanje predloga prostorskega načrta Mestne občine Ljubljana iz leta 2008. V uvodu je pojasnjen izraz sekundarno gospodarsko središče, nato je predstavljena osnovna tipologija sekundarnih gospodarskih središč, ki temelji na zgodovinskem pristopu in pomeni inventarizacijo omenjenih središč v Ljubljani. Predstavljene so izbrane značilnosti teh središč, zlasti s poslovnega vidika. Podrobneje so predstavljeni struktura podjetij, čas njihove ustanovitve, lastništvo kapitala in velikost podjetij. V drugem sklopu se nato na podlagi analize predloga prostorskega načrta ugotavlja prihodnje spreminjanje sekundarnih gospodarskih središč, njihovo nastajanje in izginjanje. Na podlagi preprostih meril je nato kritično ovrednoten predlog prostorskega načrta Mestne občine Ljubljana, izpostavljenih pa je tudi šest najbolj kritičnih sekundarnih gospodarskih središčc, ki pomembno odstopajo od postavljenih meril.

Ključne besede: gospodarsko središče, gospodarska cona, prostorsko načrtovanje, urbana ekonomija, Ljubljana, Slovenija 


\section{Uvod}

Nastajanje in širjenje novih poslovnih, nakupovalnih, obrtnih in podobnih gospodarskih območij je gotovo ena opaznejših potez v Ljubljani in širši mestni regiji. Gre za odraz temeljnih družbenih, političnih in gospodarskih sprememb v zadnjih 20 letih, ki se povezuje z nastankom postindustrijskega mesta. $\mathrm{Na}$ sektorski ravni gre za preoblikovanje ekonomske baze mesta iz industrije v storitve, kar se kaže v preoblikovanju nekdanjih industrijskih con, na mestu katerih nastajajo poslovni parki, nakupovalna središča, servisne, zabaviščne in druge dejavnosti. Hkrati pa gre tudi za temeljito preoblikovanje družbe kot celote - individualizacija, privatizacija, rast podjetniške iniciative, spremembe v mobilnosti prebivalstva in drugi družbeni dejavniki prav tako vplivajo na širjenje in preoblikovanje teh gospodarskih območij. Takšna območja očitno nudijo boljše pogoje za razvoj podjetništva kot tradicionalne središčne lokacije v strnjenem delu mestnega prostora. Hkrati pa ima Ljubljana posebno vlogo, saj je zaradi svoje dominantnosti v slovenskem urbanem sistemu središče investicijske aktivnosti, kar se prostorsko kaže prav v nastajanju poslovnih, proizvodnih in drugih stavb ter s tem vpliva na nastajanje sekundarnih gospodarskih središč.

Z izrazom sekundarno gospodarsko središče označujemo tisto območje, ki je zunaj strnjenega mesta ali na njegovem obrobju in na katerem so zgoščene poslovne in spremljajoče dejavnosti. Izraz izhaja kot protiutež » primarnemu « ali osrednjemu poslovnemu območju, ki je običajno v središču mesta (ang. central business district, $s$ kratico CBD). Izraz se sicer uporablja $\mathrm{v}$ urbanogeografskih raziskavah (Pak in Rus, 2005) in najbrž izhaja iz pragmatičnih potreb po razlikovanju med CBD-jem in novejšimi gospodarskimi središči, ki se razlikujejo v mnogih zgodovinskih, morfoloških in funkcijskih vidikih. Kljub vsemu pa je treba poudariti, da je tudi CBD le ena od oblik gospodarskih središč, sicer edinstvena, ki pa ni predmet te raziskave. Glede na prevladujočo funkcijo posameznih gospodarskih območij uporabljamo tudi druge izraze: industrijsko, obrtno, poslovno, nakupovalno, storitveno središče. Izrazu središče prav tako dajemo prednost pred izrazom »cona «. V tem prispevku smo se osredotočili na sekundarna gospodarska središča, torej brez osrednjega poslovnega središča v središču mesta.

Nastajanje sekundarnih gospodarskih središč na obrobju, zlasti na opuščenih proizvodnih, logističnih in drugih površinah, je tako logična posledica urbanega razvoja: za klasičen industrijski urbani razvoj je bila značilna središčnost in koncentracija gospodarskih dejavnosti v strnjenem delu mesta, ki se v neoklasičnih teoretskih modelih rabe tal praviloma poimenuje kot osrednje poslovno območje. Postindustrijska faza urbanega razvoja, ki jo označuje spremenjen način gospodarjenja (postfordističen $s$ fleksibilnejšo proizvodnjo, krajšimi proizvodnimi cikli, z iskanjem tržnih niš, s spremembami v delovni sili, z internacionalizacijo gospodarstva), pa se običajno enači z izgubljanjem pomena CBD, s selitvijo določenih aktivnosti v obmestni in predmestni prostor, kjer so večja fleksibilnost lokacij, nižji stroški poslovanja in boljša dostopnost (Hall, 1997; Soja 2000). Središče mesta izgublja določene funkcije, vendar hkrati pridobiva nove, zlasti tiste, povezane s potrošnjo. Zaradi večje funkcijske prepletenosti odnosov med strnjenim mestom (primarnim gospodarskim središcem) in mestnim obrobjem (sekundarnimi gospodarskimi središči) so tokovi mobilnosti prebivalstva bolj razpršeni.

Nastajanje robnih ali sekundarnih gospodarskih središč (poslovnih, nakupovalnih, pisarniških, tehnoloških in številnih drugih) je najpogosteje povezano z logičnim nadaljevanjem suburbanizacije, ko začnejo demografskim tokovom v smeri razpršitve iz mest v obmestni prostor slediti tudi industrijske in storitvene dejavnosti (Ravbar, 2005). Glavni razlog je v novih lokacijskih pogojih za podjetja, ki si od lokacije na obrobju obetajo nižje transportne in komunikacijske stroške, nižje stroške, izhajajoče iz aglomeracije podobnih podjetij (skupna infrastruktura, bližina podobnih in podpornih podjetij), ter nazadnje nižje gradbene stroške in cene zemljišč. Prednost bolj robnih lokacij za določene gospodarske aktivnosti pa je tudi v dostopnosti do potrošnikov. Težišče bivanja se je zaradi motorizacije in suburbanizacije prebivalstva nedvomno spremenilo, zato se zlasti oskrbna območja umeščajo bližje avtocestam, saj je tam dostopnost in možnost uporabe osebnega avtomobila optimalna.

Kljub veliki prepoznavnosti teh sprememb v prostoru pa novejša gospodarska središča niso pogosta tema raziskovanj. Deloma zato, ker že pojem »gospodarsko območje/cona « zaobjema tako širok spekter dejavnosti, ki jih raziskovalci težko obravnavajo znotraj enotnega teoretskega okvira. Zato so pogostejše raziskave le enega izmed tipov sodobnih gospodarskih območij, na primer nakupovalnih središč, visokotehnoloških poslovnih con, obrtnih con ... Kljub vsemu pa je treba priznati, da so rast, širjenje in preobrazba teh različnih gospodarskih območij del iste zgodbe - postindustrijske delitve dela -, pri kateri se posamezna območja, običajno na robu mesta, specializirajo $\mathrm{v}$ določen tip gospodarske dejavnosti, odvisno od lokalnih pogojev. Opaziti je mogoče, da so se v zadnjih desetletjih (pre) oblikovala novejša poslovna območja, ki pridobivajo določene gospodarske funkcije in pomenijo novo geografsko podobo mesta. Ta ni več enosrediščna, ampak je večsrediščna - izoblikovala so se sekundarna gospodarska območja, ki so deloma odraz seljenja določenih aktivnosti iz strnjenega mesta, deloma pa so odraz vse večje podjetniške aktivnosti.

Glavni cilj prispevka je poskusiti prikazati kompleksnost in raznovrstnost sodobnih gospodarsko pomembnih središč $\mathrm{v}$ 
prostoru Ljubljane ter njihovo funkcijsko in prostorsko strukturo; poskusiti se opredeliti do njihovega prihodnjega razvoja in na njih pogledati tudi skozi prizmo sprejemanja aktualnega občinskega prostorskega načrta MOL. V prvem delu smo tipizirali gospodarska središča glede na njihov zgodovinski razvoj, nato pa smo z analizo poslovnih subjektov opredelili njihovo funkcijo in gospodarsko strukturo. Analiza je uporabna tudi kot strokovna podlaga za vrednotenja osnutka prostorskega akta. V drugem delu smo se posvetili gospodarskim središčem v predlogu prostorskega načrta in jih kritično ovrednotili. Predstavili smo prostorske in funkcijske spremembe, ki jih prinaša osnutek prostorskega akta, in se do teh sprememb tudi opredelili. Na podlagi postavljenih meril smo izločili tista območja, za katera je smiselna ponovna presoja ustreznosti lokacij ,in postavili nekaj tehtnih vprašanj, ki se nanašajo na razvoj gospodarskih središč.

\section{Poskus tipizacije gospodarskih središč}

Terminoloških zadreg pri poimenovanju gospodarskih središč je veliko in zahtevajo posebno obravnavo (glej Čok, 2003). Iz vseh definicij gospodarskih središč pa lahko sklepamo, da gre za zaokrožena prostorska območja z aglomeracijo gospodarskih združb in njim pripadajočo skupno infrastrukturo (prometno, komunikacijsko, komunalno ...). Poimenovanje gospodarskih središč ni poenoteno ne v strokovnih raziskavah ne v zakonodaji, na primer v Prostorskemu redu Slovenije (Ur. l. RS, št. 60/2004) ali drugih prostorskih dokumentih. Podobno velja tudi za sicer redke opravljene tipizacije gospodarskih središc: Bogomir Filipič (2000) jih tipizira na podlagi velikosti, Andrej Gulič and Luka Mladenovič (2009) pa na podlagi njihovega vpliva oziroma zaledja.

Tuji avtorji so presojali posamezna funkcijska območja (industrijo, storitve, oskrbo), vendar zlasti z morfološkega vidika, ki vključuje analizo morfoloških elementov mesta, na primer tlorisa, tipa zazidave in zgradb (Rebernik, 2000). Harold Carter (1972) je tako glede na morfološki značaj razlikoval te tipe lokacij industrije:

- središčne lokacije, na katere se je umeščala zlasti industrija, ki je potrebovala dober dostop do delovne sile ali tržišča; sem spadajo tako različne tiskarne dnevnega časopisja kot »lahka « industrija, ki je oskrbovala podjetja $\mathrm{v}$ osrednjem poslovnem središč (CBD);

- lokacije ob pristaniščih;

- radialne lokacije, ki so posledica umeščanja ob prometnicah, kamor se naseli zlasti industrija, ki potrebuje surovine zunaj mestnega območja;

- lokacije v suburbaniziranem okolju, na katere se umešča industrija, ki potrebuje veliko prostora ali pa proizvaja velike količine zdravju škodljivih emisij.
Pogoste so bile tudi klasifikacije na podlagi velikosti tržišča, ki ga ima določen tip gospodarskih dejavnosti. Ta način se je uveljavil zlasti pri preučevanju oskrbnih središč. Michael Pacione (2001) na primeru angleških mest razlikuje med supermarketi in hipermarketi, na podlagi gravitacijskega območja pa jih deli $\mathrm{v}$ štiri glavne skupine: nakupovalna središča (oskrbujejo med 20.000 in 40.000 prebivalci); lokalna nakupovalna središča (oskrbujejo do 200.000 prebivalcev); regionalna nakupovalna središča (zaledje z do 500.000 prebivalci); nadregionalna nakupovalna središča (zaledje z več kot 500.000 prebivalci).

Prav tako obstaja nekaj poskusov tipologije poslovnih (storitvenih) središč. Hans Carol (1960, navedeno v Carter, 1972) je poslovna središča razvrstil v štiri razrede:

- osrednje poslovno središče (CBD), ki oskrbuje vse mesto;

- regionalno poslovno središče, ki oskrbuje do 100.000 prebivalcev;

- četrtno poslovno središče, ki ponuja storitve nižjega reda in oskrbuje do 10.000 prebivalcev, in

- lokalno poslovno središče, ki je običajno zgostitev lokalnih trgovin.

Brian J. L. Berry in Frank E. Horton (1970) sta na podlagi študij ameriških mest ustvarila tipologijo poslovnih območij zunaj $\mathrm{CBD}$. Območja sta glede na prostorsko obliko razčlenila v tri osnovne tipe: poslovna središča; poslovne proge, ki nastanejo linearno ob prometnicah, vpadnicah; specializirana območja, kot so zabavišča, zdravstvena središča in podobno. Za vsako izmed oblik sta izdelala tudi hierarhično lestvico, pri čemer je kot najvišja stopnja opredeljeno osrednje poslovno središč mesta (CBD), sledijo pa mu regionalna, četrtna, lokalna in ostala središča. Poslovne proge sta razdelila v štiri hierarhične stopnje, specializirana poslovna območja pa v šest hierarhičnih stopenj. Ron J. Johnston (1971, navedeno v Carter, 1972) je ugotavljal značilnosti teh poslovnih območij in ugotovil, da je hierarhični položaj območja tesno povezan s tipom storitev, ki so tam locirane; storitve nižjega reda se osredotočajo v središčih ali progah nižjega reda in obratno.

V sodobnosti se z lokacijami poslovnih, zlasti pisarniških območij, največ ukvarja Lang, ki je skupaj s kolegoma na primeru trinajstih ameriških mest ugotovil, da se pojavljajo v številnih oblikah (Lang idr., 2006). V osrednjem poslovnem središču (CBD) je še vedno okrog tretjina poslovnih dejavnosti, preostanek pa je razpršen tako znotraj strnjenega dela mesta kot drugod v mestni regiji. Znotraj strnjenega dela mesta se izoblikujejo posamezna izolirana območja, pri katerih gre dejansko za razlitje nekaterih dejavnosti iz CBD na ugodnejša območja, ki jih Lang idr. (2006) imenujejo »urbane ovojnice« (ang. urban envelopes). Zunaj mesta se poslovne dejavnosti rade osredotočajo $\mathrm{v}$ robnih mestih (ang. edge cities), ki nastanejo $s$ 
hitro rastjo in krepitvijo zlasti zaposlitvenih funkcij manjših obmestnih naselij.

Omenjene vrste tipizacij za naš namen niso najprimernejše. Ljubljana ima svojstven zgodovinski razvoj, na podlagi katerega lahko izločimo posamezna značilna območja zgoščevanja gospodarskih aktivnosti. Glede na nastanek in glavne sektorske usmeritve lahko v Ljubljani izločimo več različnih tipov gospodarskih središč. V osnovi jih lahko ločimo na podlagi njihovega zgodovinskega razvoja. Nedvomno so tako najstarejša gospodarska središča v Ljubljani industrijska območja, ki so obstajala že pred drugo svetovno vojno. To so »točkovna « območja tovarn, kot so Union, Ilirija, Tobačna in podobnih, ki so bližje mestnemu središču, in tudi tiste, ki so umeščene zunaj strnjenega mesta (Papirnica Vevče, tovarna Totra in podobno). Nekatere ohranjajo svojo dejavnost, druge pa so v fazi preobrazbe, v kateri ohranjajo vidno podobo, vendar menjajo funkcijo, kot na primer Tobačna tovarna.

Naslednji značilni tip so gospodarska središča iz časa po drugi svetovni vojni. Nastanek industrijskih con ob vseh glavnih prometnicah je gotovo zaznamoval socialistično Ljubljano, prav tako pa tudi nastanek oskrbno-storitvenih dejavnostih ob glavnih vpadnicah in drugih primernih območjih. Večinoma gre za linearen razvoj ob prometnicah, ki se je sčasoma širil iz središča mesta navzven (Pak, 2000). Površinsko so to zelo obsežne površine v Ljubljani, med največje pa spada industrijsko-logistična cona v Mostah in industrijska cona v Šiški. Oskrbno-storitvena območja so se sicer razvila že na prej poseljenih območjih ob mestnih vpadnicah, vendar so dobila popolnoma nove funkcije, med katerimi so izstopale zlasti trgovske in upravne.

Po letu 1990 je nastala nova prelomnica. Poleg funkcijskih sprememb znotraj takrat obstoječih gospodarskih središč so se pričela oblikovati tudi nekatera popolnoma nova območja. Gre za izključno oskrbna in storitvena območja, saj industrijskega razvoja greenfield v Ljubljani pravzaprav ni. Ta območja so nastala kot posledica velikega interesa domačih in tujih investitorjev, pomembno vlogo pa je imela tudi občina z določenimi razvojnimi projekti (na primeru Tehnološkega parka Brdo).

Ne smemo pa pozabiti še na dve gospodarsko izjemno pomembni območji v Ljubljani, ki sta značilni za vsako sodobno mesto: zgodovinsko jedro in osrednje poslovno območje (CBD). Opredeljeni sta bili že v drugih raziskavah (glej Genorio, 1978, ali Pak, 2000) in imata kljub vse bolj poudarjenemu razvoju mestnega obrobja še vedno pomembno gospodarsko vlogo.

Na podlagi zgoraj omenjenih zgodovinskih izhodišč lahko izločimo tipe gospodarskih središ v v Ljubljani, ki so prikazani v preglednici 1. Pomembno je še poudariti, da smo pri časovnem vrednotenju upoštevali, kdaj je določeno gospodarsko središče dobilo svojo današnjo obliko (zazidavo), funkcijo pa pripisali glede na trenutno stanje. Območje Blagovno-trgovskega centra (v nadaljevanju: BTC) je tako označeno kot oskrbno in storitveno središče - kar danes nedvomno je -, območje pa je bilo v glavnem pozidano in oblikovano po drugi svetovni vojni do leta 1990, čeprav se je tudi kasneje s prestrukturiranjem prostorsko spreminjalo.

Preglednica 1: Pregled in pripadajoče površine glede na posamezne zgodovinske tipe gospodarskih središč v Ljubljani

\begin{tabular}{ll}
\hline A) Primarni gospodarski središči: & velikost \\
\hline 1. zgodovinsko mestno jedro & 22 ha \\
\hline 2. osrednje poslovno središče (CBD) & 107 ha \\
\hline B) Sekundarna (robna) gospodarska središča: & \\
\hline $\begin{array}{l}\text { Industrijska središča, nastala pred drugo svetovno } \\
\text { vojno: }\end{array}$ & 76 ha \\
\hline \begin{tabular}{l} 
3. (a) še vedno dejavna \\
\hline 3. (b) v fazi opuščanja, preobrazbe
\end{tabular} & 41 ha \\
\hline $\begin{array}{l}\text { Središča, nastala po drugi svetovni vojni do leta } \\
\text { 1990: }\end{array}$ \\
\hline \begin{tabular}{l} 
industrijska/obrtna središča: \\
\hline 4. (a) še vedno dejavna
\end{tabular} \\
\hline $\begin{array}{l}\text { 4. (b) v fazi opuščanja industrijske/obrtne funkcije, } \\
\text { preobrazbe }\end{array}$ & 45 ha \\
\hline 4. (c) oskrbna in druga storitvena središča & 189 ha \\
\hline \begin{tabular}{l} 
Središča, nastala po letu 1990 (razvoj greenfield): \\
\hline 5. (a) oskrbna (nakupovalna) središča
\end{tabular} \\
\hline $\begin{array}{l}\text { 5. (b) druga storitvena središča (pisarniška, } \\
\text { tehnološka in podobna) }\end{array}$ \\
\hline \begin{tabular}{l} 
Skupaj: \\
\hline
\end{tabular}
\end{tabular}

Vir: Bole in Ravbar (2009)

Prostorski obseg zgodovinskega mestnega jedra in osrednjega poslovnega območja je bil popolnoma opredeljen že v prejšnjih raziskavah funkcijske in morfološke zgradbe Ljubljane (na primer Pak, 2000, ali Rebernik, 2000). Ostale omenjene tipe posameznih gospodarskih središč v Ljubljani smo poskušali prostorsko omejiti na podlagi strokovne ocene in kartiranja letalskih posnetkov z leta 2007. Tista središča, ki so bila med kartiranjem le deloma preoblikovana (Mesarija), ali pa središča $\mathrm{z}$ opuščeno industrijsko funkcijo ter $s$ še vedno izrazito industrijsko morfologijo in pojavljajočimi se drugimi aktivnostmi (Tobačna ali Rog in Metelkova s pojavom kulturne industrije), smo združili v enotno skupino »v fazi opuščanja/preobrazbe «. Takšna območja imajo namreč veliko možnosti, da v prihodnje postanejo središčni kraji tako imenovane »kulturne proizvodnje in ostalih specializiranih storitev « (Bole, 2008a: 275), zato smo jih umestili v posebno skupino. V to skupino smo izjemoma vključili tudi območje Metelkove, ki ni nikoli imelo industrijske funkcije, vendar gre za pomembno območje 
kulturne industrije v Ljubljani, ki je bilo pozidano pred drugo svetovno vojno in je nekoč imelo pomembno vojaško funkcijo.

Manjših »točkovnih « površin z gospodarskimi dejavnostmi (na primer posamezno podjetje) nismo kartirali, osredotočili smo se na površinsko obsežnejša območja, ki imajo običajno večje število gospodarskih subjektov, kar je lahko tudi opredelitev gospodarskega središča kot območja delovanja več gospodarskih združb. Funkcijska pestrost takih območij je seveda izjemna, zato so potrebne določene generalizacije in kompromisi. Zlasti oskrbno-storitvene dejavnosti niso le kraj, na katerem potekajo gospodarske aktivnosti, ampak so tudi kraj bivanja in imajo izrazito mešano rabo prostora. Podobno težko je ločevanje med novejšimi oskrbnimi in ostalimi storitvenimi območji, ki so nastala po 1990, saj se ti funkciji pogosto dopolnjujeta (pisarne in nakupovanje). Območje BTC je pretežno storitveno in oskrbno, vendar ima dobro razvito tudi proizvodno funkcijo, ki pokriva $19 \%$ vseh površin (Bole, 2008b). Podobno velja za zahodni del gospodarskega središča v Stegnah, v katerem se poleg proizvodne vse bolj uveljavlja trgovska funkcija in ustvarja večfunkcijsko središče (Bole, 2008a), kar je značilnost sodobnih gospodarskih središč. Kljub vsemu smo zaradi lažjega razumevanja strukture posameznih gospodarskih središč - ob zavedanju vseh pomanjkljivosti omenjene metode - poskušali opraviti omenjeno razlikovanje in tipizacijo.

Območja so tipizirana na podlagi dveh meril. Prvo je trenutno stanje oziroma obseg, ki smo ga določali s pomočjo kartiranja letalskih posnetkov in ažuriranja stanja na terenu, drugo pa poznavanje zgodovine nastanka in preobrazbe določenega območja, ki smo ga določali s pomočjo starejših zemljevidov in literature. Na podlagi te metode smo izdelali zemljevid gospodarskih središč $v$ Ljubljani glede na posamezne zgodovinske tipe. Zavedamo se, da so nekatera središča funkcijsko tako zelo raznovrstna, da je uvrščanje celotnega območja v le en tip lahko zavajajoče. Vendar vsaka tipizacija že v osnovi generalizira dejansko stanje, zato je umeščanje posameznega območja tudi subjektivne narave - omenjeno dejstvo je tudi največja slabost te tipizacije.

Od skupno 944 hektarjev imajo največji delež industrijske cone, nastale med letoma 1945 in 1990, pri čemer poudarjamo, da gre za dejansko in ne plansko stanje. Trenutno veljavno načrtovalno stanje ne omogoča primerjave $\mathrm{z}$ našo tipizacijo gospodarskih središč. Leta 2004 je bilo na primer za industrijo namenjenih več kot 1.200 hektarjev načrtovalnih površin

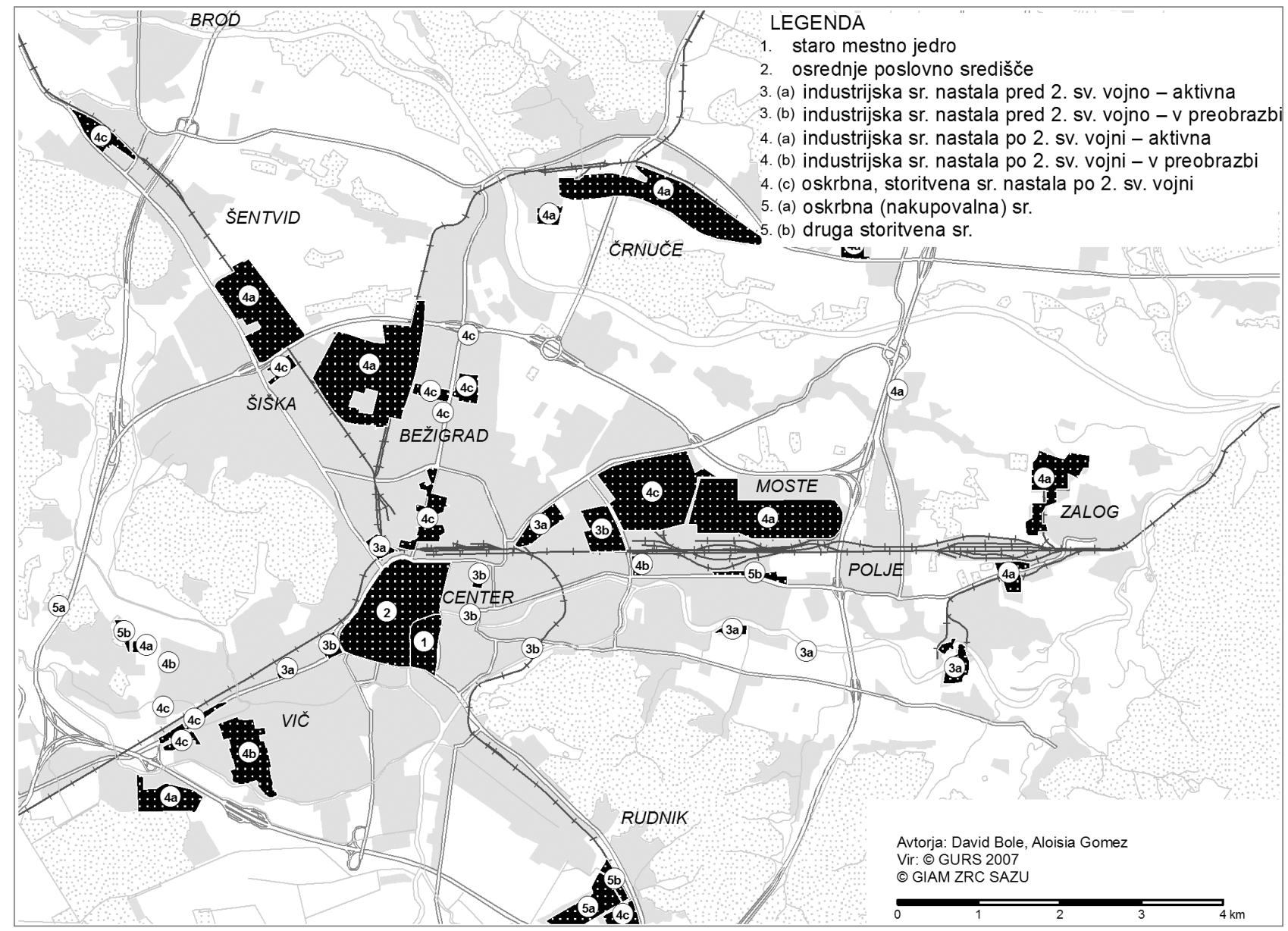

Slika 1: Zgodovinski tipi gospodarskih središč v Ljubljani (Bole in Ravbar, 2009) 
(Kavaš in Koman, 2007), vendar ponekod prevladujejo oskrbne in druge storitvene funkcije. Tudi popolnoma storitvena središča (BTC) so $\mathrm{v}$ veljavnem dolgoročnem prostorskem načrtu občine še vedno označena $s$ proizvodno in skladiščcno namensko rabo prostora (Dolgoročni plan ..., Ur. l. SRS, št. 11/1986). Kljub temu pa so zanimive določene primerjave posameznih tipov - investicij greenfield (območij, nastalih po letu 1990 na prej nepozidanih površinah) je tako samo za $5 \%$ skupnih površin gospodarskih območij, kar je presenetljivo, saj nekateri avtorji omenjajo te investicije kot prevladujočo prostorsko obliko v tranzicijskih mestih (glej Burdack in Bontje, 2005, ali Tosics, 2005). Še vedno pa zavzemajo relativno veliko prostora starejša, predvojna industrijska območja, skupaj $8 \%$ ali 76,4 hektarjev površin.

\section{Analiza izbranih značilnosti sekundarnih gospodarskih središč}

\subsection{Kratek opis metode dela}

V nadaljevanju smo za vsako sekundarno gospodarsko območje v Ljubljani analizirali podjetniško sestavo, in sicer glede na usmeritev dejavnosti, starost podjetij, lastništvo podjetij in velikost podjetij. Poskušali smo ugotoviti razlike med posameznimi gospodarskimi območji v Ljubljani in se opredeliti tudi do vzrokov za te razlike. $S$ poglobljeno analizo smo poskušali prikazati tudi širši funkcionalni pomen posameznih sekundarnih gospodarskih območij v Ljubljani. Nadalje smo kartirali in podrobno analizirali vsa sekundarna gospodarska območja, ki obsegajo 20 hektarjev površine ali več. Z analizo smo zbirali te podatke (Bole in Ravbar, 2009):

- velikost območja v hektarjih je bila določena glede na digitalizacijo letalskih posnetkov iz leta 2007, ki so bili pridobljeni leta 2009 in ažurirani s terenskim pregledom;

- določali smo možnost predvidene širitve na podlagi večjega števila meril: prvo merilo je lokacija cone - če je obkrožena z že poseljenimi površinami in hkrati notranje popolnoma zapolnjena je možnost širjenja gospodarskih aktivnosti precej otežena; pomagali smo si tudi s najnovejšim predlogom Izvedbenega prostorskega načrta MOL ( $v$ nadaljevanju: IPN MOL), ki pa je še vedno v postopku sprejemanja in revidiranja;

- bližina ostalih gospodarskih con je bila določena na podlagi GIS orodij in zaokrožena na 50 metrov;

- število poslovnih subjektov je bilo določeno s pomočjo Poslovnega registra Slovenije (v nadaljevanju: PRS), s stanjem, veljavnim februarja 2009;

- prve tri glavne dejavnosti so bile prav tako določene $s$ PRS in smiselnim zaokroževanjem številnih dejavnosti po standardni klasifikaciji dejavnosti v nekaj 10 skupin;
- poreklo kapitala je bilo določeno s PRS v tri skupine: tuj, mešan in domač ustanovitelj podjetja;

- delež srednjih in velikih podjetij je bil določen na podlagi evropske metodologije v PRS, v kateri imajo srednje velika podjetja od 10 do 200 zaposlenih, velika pa nad 200 zaposlenih (Bole, 2008b);

- delež podjetij, ki so nastala po letu 2005, je podatek, ki smo ga pridobili iz PRS;

- prostorska struktura je najbolj subjektiven podatek; želeli smo ugotoviti, ali ima določeno središče pravilno kare zazidavo z vidnim mrežnim rasterjem; vidnost te zazidave smo določali z letalskega posnetka in ga subjektivno uvrstili v razrede: zelo vidna, srednje vidna, slabo vidna in nevidna oziroma mešana zazidava;

- namenska raba je bila določena glede na trenutno veljavno stanje prostorskih sestavin dolgoročnega prostorskega plana MOL (Dolgoročni plan ..., Ur. l. SRS št. 11/1986);

- povezanost $s$ cestno infrastrukturo je bila določena na podlagi mreže državnih cest iz leta 2005, ločili smo le tri glavne skupine cest: avtoceste (AC), regionalne ceste (RC) in lokalne ceste (LC), slednje so v pristojnosti lokalnih oblasti; avtoceste sicer le redko neposredno prečkajo gospodarska območja, zato smo upoštevali tudi neposredne ali bližnje dovoze na avtocesto;
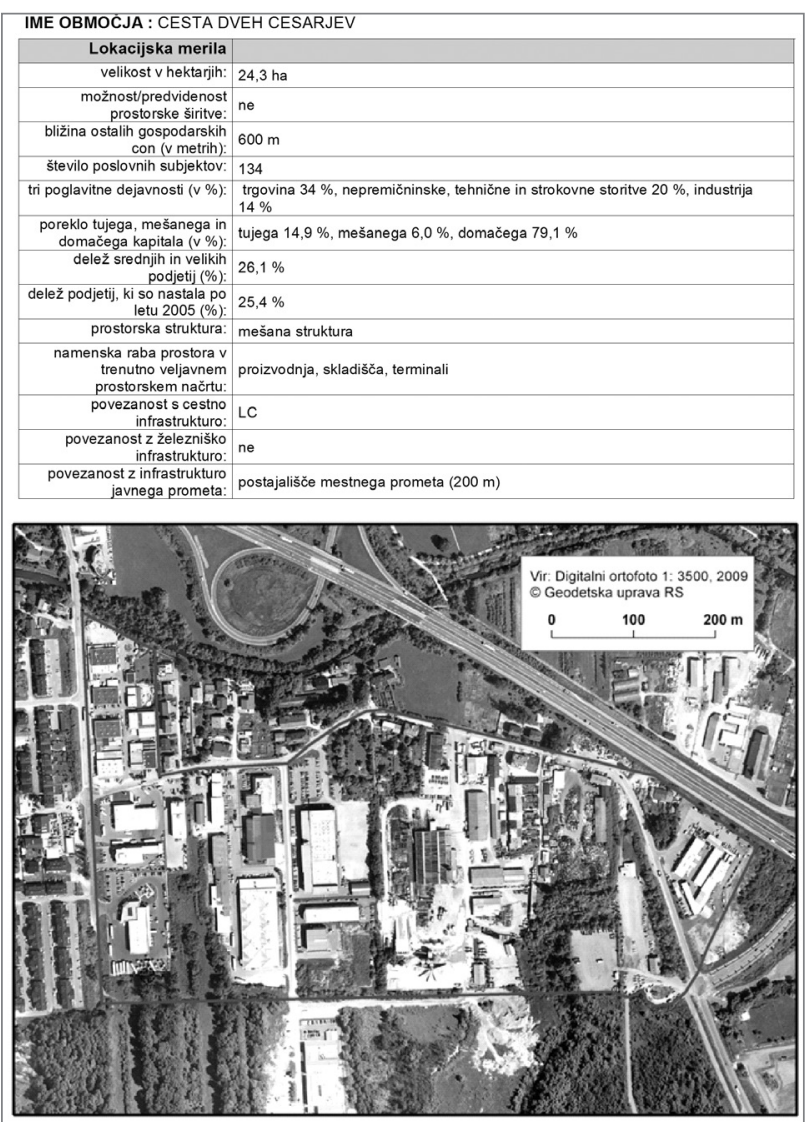

Slika 2: Primer kartice posameznega sekundarnega gospodarskega središča (Bole in Ravbar, 2009) 
- povezanost z železniško infrastrukturo smo ugotavljali s pomočjo kart; ponekod železnica sicer prečka gospodarske cone, vendar z njimi ni funkcionalno povezana, zato je nismo upoštevali;

- povezanost z infrastrukturo javnega prometa smo določali s pomočjo svoje baze postajališč javnega potniškega prometa v Sloveniji.

Za vsako sekundarno središče smo oblikovali pregledne kartice $\mathrm{z}$ vsemi omenjenimi informacijami, kot je prikazano na sliki 2.

\subsection{Gospodarske funkcije sekundarnih gospodarskih središč}

Analiza PRS nam omogoča natančno analizo usmerjenosti dejavnosti posameznih gospodarskih središč. V vseh prikazanih zgodovinskih tipih gospodarskih središč Ljubljane je skoraj 12.300 poslovnih subjektov, kar znaša več kot $38 \%$ vseh poslovnih subjektov v MOL. V sekundarnih gospodarskih središčih močno prevladujeta funkciji trgovine na debelo in trgovine na drobno, ki pomenita $30 \%$ vseh poslovnih subjektov. Pomembne so še dejavnosti strokovnih, tehničnih in nepremičninskih storitev, ki pomenijo dobrih $17 \%$ podjetij, medtem ko je v gradbeništvu $8 \%$ in industriji $6 \%$ podjetij. Pretežno javne storitve (uprava, zdravstvo, šolstvo) so priča- kovano podpovprečno zastopane, saj znaša njihov delež v sekundarnih gospodarskih središčih le dobrih 3,5\%, v celotni občini pa $19 \%$.

Analiza poslovnih subjektov po glavni dejavnosti glede na posamezne zgodovinske tipe pokaže nekaj zanimivih rezultatov (preglednica 2). Industrija je še vedno najbolj značilna za starejša industrijska območja, ki so nastala pred drugo svetovno vojno. Novejši ko je nastanek območij, manjša je njihova industrijska funkcija. Deleži industrije so sicer precej majhni in se gibljejo med 1 in $14 \%$, vendar je treba vedeti, da so industrijski poslovni subjekti v povprečju precej večji kot tisti iz storitvenih dejavnosti (Bole, 2008b). Izrazite so še razlike pri trgovskih poslovnih subjektih, pri katerih izstopajo novejša oskrbna središča, ki so nastala po letu 1990, na primer Nakupovalno središče Rudnik in Lesnina. V omenjenih območjih je več kot dve tretjini poslovnih subjektov v trgovski dejavnosti, ostale so precej zanemarljive. Zanimiva so še novejša storitvena središča, nastala po letu 1990 (Tehnološki park, Rudnik), v katerih prevladujejo tehnične in strokovne storitve, med katere se uvrščajo arhitekturni biroji, tehnološka, informacijska in visokotehnološka podjetja. Iz preglednice je torej razvidno, da zgodovinska tipizacija hkrati pomeni tudi določeno funkcijsko tipizacijo, saj se nekateri tipi gospodarskih območij medsebojno pomembno razlikujejo po sestavi poslovnih subjektov.

Preglednica 2: Deleži poslovnih subjektov v posameznih zgodovinskih tipih gospodarskih središč Ljubljane glede na glavno dejavnost, ki jo opravljajo.

\begin{tabular}{|c|c|c|c|c|c|c|c|}
\hline Tip dejavnosti & $\begin{array}{l}\text { Industrijska } \\
\text { območja pred } \\
\text { letom } 1945\end{array}$ & $\begin{array}{l}\text { Industrijska } \\
\text { območja pred } \\
\text { letom } 1945 \text { - } \\
\text { v preobrazbi }\end{array}$ & $\begin{array}{l}\text { Industrijska } \\
\text { območja po } \\
\text { letu } 1945\end{array}$ & $\begin{array}{l}\text { Industrijska } \\
\text { območja po } \\
\text { letu } 1945 \text { - v } \\
\text { preobrazbi }\end{array}$ & $\begin{array}{l}\text { Oskrbna, stori- } \\
\text { tvena območja } \\
\text { med letoma } \\
1945 \text { in } 1990\end{array}$ & $\begin{array}{l}\text { Oskrbna } \\
\text { območja po } \\
\text { letu } 1990\end{array}$ & $\begin{array}{l}\text { Storitvena, } \\
\text { pisarniška } \\
\text { območja po } \\
\text { letu } 1990\end{array}$ \\
\hline industrija & 13,77 & 8,25 & 7,81 & 8,35 & 3,32 & 0,91 & 4,48 \\
\hline gradbeništvo & 14,86 & 11,34 & 9,19 & 17,04 & 5,51 & 2,73 & 5,22 \\
\hline komunala & 1,09 & 0,21 & 0,85 & 0,87 & 0,43 & 0,00 & 0,37 \\
\hline trgovina & 23,91 & 15,46 & 29,01 & 21,91 & 36,73 & 69,09 & 24,63 \\
\hline popravila & 0,36 & 0,41 & 0,53 & 0,52 & 0,30 & 0,00 & 0,00 \\
\hline promet & 6,88 & 3,09 & 3,60 & 1,39 & 1,63 & 0,00 & 2,61 \\
\hline telekomunikacije & 3,26 & 5,77 & 6,25 & 6,26 & 4,85 & 0,00 & 14,93 \\
\hline nepremičnine & 2,17 & 2,47 & 4,06 & 2,43 & 5,08 & 6,36 & 4,85 \\
\hline tehnične, strokovne storitve & 12,68 & 17,11 & 18,27 & 18,61 & 16,77 & 2,73 & 24,63 \\
\hline turizem & 5,07 & 2,47 & 2,69 & 3,13 & 4,68 & 10,00 & 2,61 \\
\hline finance & 1,81 & 1,65 & 4,38 & 1,22 & 4,52 & 0,91 & 2,61 \\
\hline druge poslovne storitve & 2,54 & 4,12 & 2,33 & 1,74 & 2,29 & 0,00 & 2,24 \\
\hline izobraževanje & 0,36 & 3,09 & 1,38 & 1,74 & 1,49 & 0,00 & 1,12 \\
\hline kultura, šport & 1,45 & 5,36 & 2,12 & 2,26 & 3,02 & 0,00 & 0,75 \\
\hline uprava & 0,36 & 1,24 & 0,21 & 0,17 & 0,63 & 0,00 & 0,00 \\
\hline zdravstvo & 1,45 & 1,86 & 1,13 & 4,17 & 1,30 & 0,00 & 5,97 \\
\hline ostalo & 7,97 & 16,08 & 6,18 & 8,17 & 7,44 & 7,27 & 2,99 \\
\hline
\end{tabular}

Vir: Agencija RS za javnopravne evidence in storitve (2009) 


\subsection{Starost poslovnih subjektov v sekundarnih gospodarskih središčih}

Določene značilnosti posameznih gospodarskih središč nam lahko prikaže tudi analiza podjetij po datumu njihovega nastanka. Če se v določeno gospodarsko središče umeščajo novejši poslovni subjekti, lahko sklepamo o določenem ciklu prenove oziroma spreminjanju strukture podjetij. Opozoriti je treba še na dejstvo, da novejši čas nastanka določenega območja ne pomeni tudi, da ima to podjetje novejše poslovne subjekte, saj se tja lahko locirajo tudi podjetja, ki imajo starejši čas nastanka in so le zamenjala lokacijo. Časovna struktura podjetij v določenem območju torej ni nujno povezana tudi s starostjo gospodarskega središča, temveč bolj z njegovo »vsebinsko « strukturo.

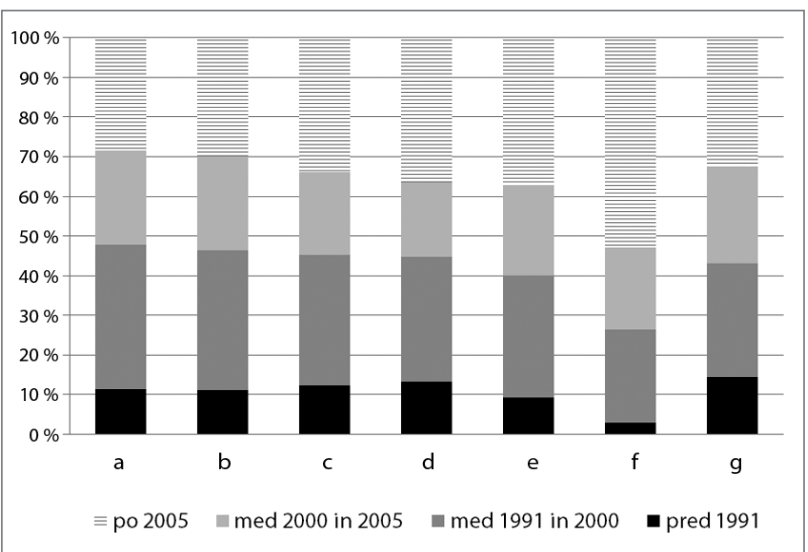

Opomba: (a) industrijska območja pred letom 1945, (b) industrijska območja pred letom 1945 - v preobrazbi, (c) industrijska območja med letoma 1945 in 1990, (d) industrijska območja med letoma 1945 in 1990 - v preobrazbi, (e) obrtna, oskrbna, druga storitvena območja med letoma 1945 in 1990, (f) novejša oskrbna območja po letu 1990, (g) novejša storitvena območja po letu 1990.

Slika 3: Deleži poslovnih subjektov v posameznih zgodovinskih tipih gospodarskih središč Ljubljane glede na čas njihovega nastanka (Bole in Ravbar, 2009)

Iz podatkov o časovni sestavi poslovnih subjektov po posameznih tipih gospodarskih središč je razvidno, da so najnovejša oskrbna območja »najmlajša « tudi z vidika starosti podjetij (slika 3). Najnovejša oskrbna območja, nastala po letu 1990, imajo več kot polovico vseh poslovnih subjektov, ki so nastali po letu 2005, in hkrati tudi najmanj podjetij, nastalih pred letom 1990. Očitno je, da so trgovska podjetja tista, ki izkazujejo največjo dinamiko nastajanja in lociranja v sekundarna gospodarska središča. Zanimiva pa so najnovejša storitvena (pisarniška) območja, ki so nastala po letu 1990, njihov delež starejših podjetij pa je celo največji $(15 \%)$. V ta sodobna pisarniška središča (na primer Tehnološki park Ljubljana) se tako umeščajo starejša in že uveljavljena podjetja, ki želijo novejše prostore s sodobnejšimi lokacijskimi in infrastrukturnimi pogoji (obrobje mesta, veliko zelenih površin, dobra povezava $s$ prometno infrastrukturo, sodobna opremljenost prostorov).

\subsection{Analiza sekundarnih gospodarskih središč glede na lastništvo kapitala}

Povprečni delež tujega kapitala v vseh središčih znaša $11 \%$. Največji delež tujega kapitala imajo poslovne cone na območjih greenfield (Rudnik in Lesnina), kjer je delež tujega kapitala trikrat večji od povprečja (34\%). Tudi delež mešanega kapitala je pri novejših oskrbnih območjih $(9 \%)$ nadpovprečno velik (slika 4).

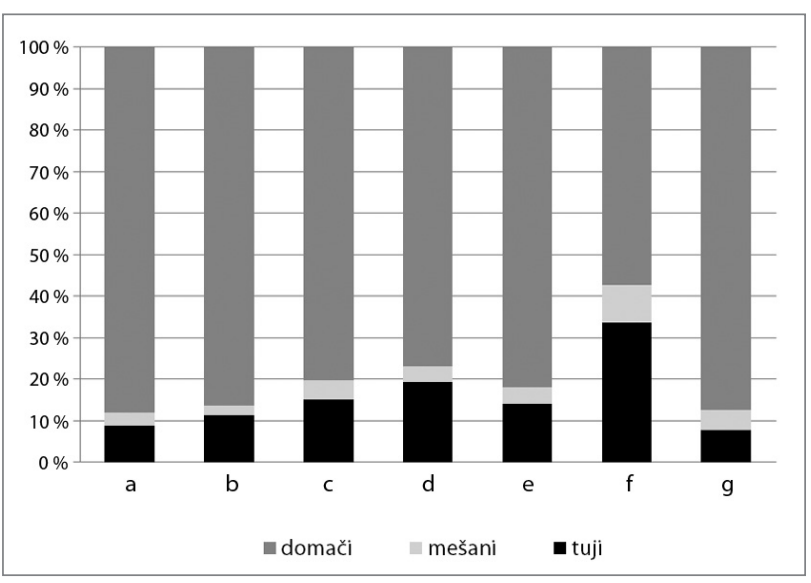

Opomba: (a) industrijska območja pred letom 1945, (b) industrijska območja pred letom 1945 - v preobrazbi, (c) industrijska območja med letoma 1945 in 1990, (d) industrijska območja med letoma 1945 in 1990 - v preobrazbi, (e) obrtna, oskrbna, druga storitvena območja med letoma 1945 in 1990, (f) oskrbna območja greenfield po letu 1990, (g) storitvena območja greenfield po letu 1990.

Slika 4: Poreklo kapitala v posameznih zgodovinskih tipih gospodarskih središč MOL (Bole in Ravbar, 2009)

Iz primerjave porekla kapitala po posameznih sekundarnih gospodarskih središčih izhaja zelo podoben vzorec kot iz zgoraj opisane analize po zgodovinskih tipih. Domači kapital ima pri vseh središčih velik delež, največji pa v starejših industrijskih središčih (Zalog, Petrol, Jata, Union), pri katerih ponekod dosega celo $100 \%$. Iz analize lahko opazimo, da imajo gospodarska središča z novejšim nastankom in nekatera večja dinamična storitvena območja več tujih podjetij, za starejša in bolj »statična « območja pa je značilna prevlada domačih podjetij. To najbrž potrjuje tezo, da je bilo storitev v preteklem družbenem sistemu zelo malo ter da so tuji investitorji, podobno kot v ostalih tranzicijskih državah, najbolj zainteresirani za investicije v storitvene in oskrbne gospodarske cone. Zato imata največji delež tujega in mešanega kapitala v Ljubljani prav oskrbni središči na Rudniku in logistično središče ob Letališki cesti v Ljubljani (slika 5). 


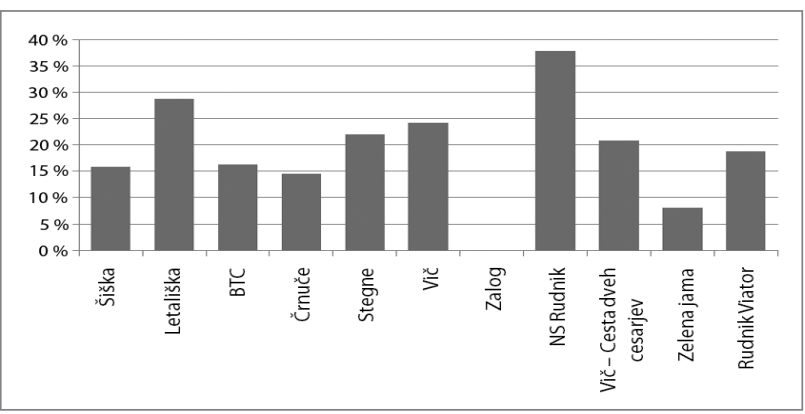

Slika 5: Delež tujega in mešanega kapitala v vseh večjih identificiranih gospodarskih središčih v Ljubljani (Bole in Ravbar, 2009)

\subsection{Analiza sekundarnih gospodarskih središč glede na velikost podjetij}

Podatki o velikosti podjetij na ravni EU so razporejeni v te kategorije: mala podjetja (od 1 zaposlenega do 9 zaposlenih), srednje velika podjetja (od 10 do 199 zaposlenih) in velika podjetja (več kot 200 zaposlenih). Iz podatkovne baze PRS smo izločili podatke kategorij $\gg 0$ zaposlenih « in $\gg$ ni podat$\mathrm{ka} \ll$. Na območjih raziskave je bilo izločenih kar $65 \%$ vseh podjetij, večinoma gre za samostojne podjetnike brez zaposlenih, društva, sindikate ali neaktivna podjetja. V sekundarnih poslovnih središčih so podjetja večinoma mala, saj jih je $75 \%$, $23 \%$ je srednje velikih podjetij in le $2 \%$ velikih podjetij z več kot 200 zaposlenimi.

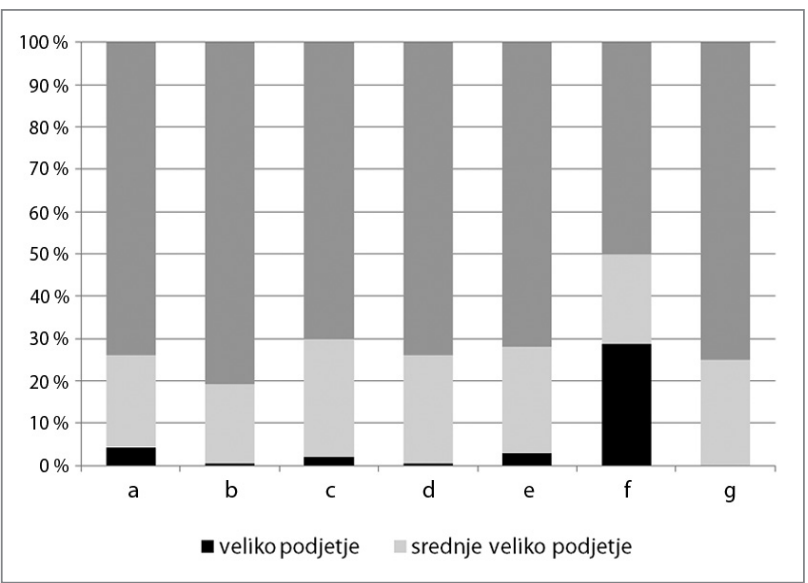

Opomba: (a) industrijska območja pred letom 1945, (b) industrijska območja pred letom 1945 - v preobrazbi, (c) industrijska območja med letoma 1945 in 1990, (d) industrijska območja med letoma 1945 in 1990 - v preobrazbi, (e) obrtna, oskrbna, druga storitvena območja med letoma 1945 in 1990, (f) oskrbna območja greenfield po letu 1990, (g) storitvena območja greenfield po letu 1990.

Slika 6: Velikost podjetji v posameznih zgodovinskih tipih gospodarskih središč MOL (Bole in Ravbar, 2009)

V splošnem lahko ugotovimo, da imajo območja v funkcijski preobrazbi bolj razdrobljeno podjetniško strukturo in podpovprečen delež velikih podjetij in da imajo industrijska območja v povprečju večja podjetja, kar je povezano z organizacijo dela $\mathrm{v}$ industriji, ki v glavnem zaposluje večje število delavcev kot storitvena podjetja (sliki 6 in 7).

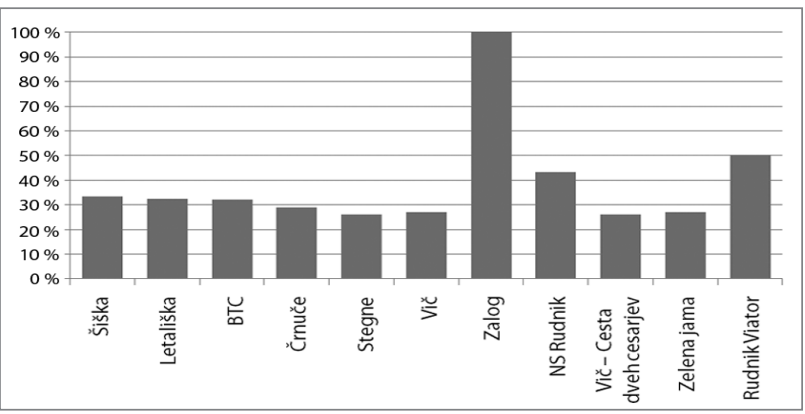

Slika 7: Delež srednje velikih in velikih podjetji v vseh večjih identificiranih gospodarskih središčih v Ljubljani (Bole in Ravbar, 2009)

\subsection{Povzetek glavnih ugotovitev analize obstoječih gospodarskih središč v Ljubljani}

Glavne ugotovitve analize poslovnih subjektov in drugih spremenljivk, ki so omenjene v poglavju 3.1, lahko strnemo v tako (Bole in Ravbar, 2009):

- Gospodarska središča v mestu Ljubljana obsegajo 944 hektarjev skupne površine.

- Največji delež imajo industrijska središča iz povojnega časa oziroma središča, nastala na teh območjih. Razvoj greenfield je značilen za manj kot $5 \%$ celotnih površin ljubljanskih gospodarskih središč.

- 11 gospodarskih središč ima nad 20 hektarjev površin, največje središč je Industrijska cona Šiška, sledita mu središči ob Letališki cesti in BTC.

- V gospodarskih središčih je najizrazitejša trgovska funkcija - tudi na območjih, ki so po načrtu še vedno predvidena za proizvodnjo: BTC, Stegne, Rudnik ... Industrija je najbolj zastopana $\mathrm{v}$ najstarejših območjih (Union, Ilirija ...), mlajša območja pa so izrazito storitveno naravnana. Javni sektor je zastopan podpovprečno.

- Struktura poslovnih subjektov po posameznih območjih je raznovrstna. Starejša podjetja, pretežno industrijska in z večjim številom zaposlenih, prevladujejo v starih in enofunkcijskih industrijskih središčih (Union, Ilirija, Cesta dveh cesarjev, Zalog). Ta območja bi lahko označili kot statična.

- Industrijske cone iz socialistične dobe in novejša storitvena središča imajo v povprečju mlajšo strukturo podjetij, bolj razdrobljeno in storitveno naravnano, kar kaže na intenzivnejši razvoj, zato bi jih lahko označili kot dinamična gospodarska območja.

S pomočjo analize lahko strnemo določene lastnosti, ki se lahko upoštevajo pri načrtovanju gospodarskih središč. Prva lastnost je zlasti večfunkcijskost. Klasičnih proizvodnih, oskrb- 
nih ali drugih enofunkcijskih gospodarskih središč ni več, kar je razvidno tudi iz analize. Načrtovanje gospodarskih središč mora to upoštevati in preprečevati poudarjanje samo industrijske ali druge funkcije. Enofunkcijska zgradba je smiselna le pri načrtovanju zelo specifičnih gospodarskih središčc, na primer logističnih. Večje industrijske obrate pa bi bilo bolj smiselno umeščati v industrijsko cono $\mathrm{v}$ Zalogu, ki ima prostorske zmogljivosti za dodatne večje proizvodne obrate. Iz rezultatov analize izhaja tudi izrazita prevlada vse manjših gospodarskih subjektov, ki so pretežno storitvene narave, kar bi pri načrtovanju gospodarskih središč morali upoštevati (tloris, prometna ureditev, parkirišča ...).

V Ljubljani je manj kot $5 \%$ gospodarskih središč nastalo na prej nepozidanih površinah, kar je z vidika sonaravnega razvoja ugodno. Da bi to edinstveno stanje ohranili, bi bilo smiselno preprečevati takšne posege tudi v prihodnje in usmerjati tuje investitorje $\mathrm{v}$ že pozidana degradirana območja - tako imenovani razvoj brownfield. Analiza tudi kaže, da je treba posebno pozornost usmeriti $v$ industrijska in obrtna središča iz povojnega časa, ki so najbolj dinamična in so v fazi temeljitega prestrukturiranja, zato je njihovo usmerjanje v smislu urbanističnega načrtovanja še posebej pomembno.

\section{Pregled predvidenega razvoja gospodarskih središč v prihodnosti}

Po osamosvojitvi Slovenije in z vstopom v tržno gospodarstvo se je prostorski razvoj temeljito spremenil. V nasprotju z ostalimi tranzicijskimi državami, ki so doživljale pretresljive spremembe $\mathrm{z}$ vidika suburbanizacije gospodarskih aktivnosti in nastajanja raznih oskrbnih, pisarniških in tehnoloških parkov v suburbaniziranih obmestjih (na primer Tosics, 2005, ali Stanilov, 2007), je imela Ljubljana drugačen razvoj. Delež investicij na mestno obrobje je bil precej manjši, saj so investicije greenfield po letu 1990 obsegale le 45 hektarjev površin. V mestni regiji so sicer pričela nastajati nova gospodarska središča v obliki raznih obrtnih, podjetniških in podobnih con (Gulič in Mladenovič, 2009).

Bolj je bilo poudarjeno prestrukturiranje znotraj obstoječih gospodarskih središč in spreminjanje njihove funkcije. To je opazno tudi iz primerjave med načrtovano in dejansko rabo tal, saj industrijska dejavnost dejansko poteka le še na 39 \% vseh površin, označenih za proizvodnjo (Kavaš in Koman, 2007). Tudi iz analize poslovnih subjektov izhaja, da so območja, na katerih prevladuje izključno industrija, redka, večinoma $\mathrm{v}$ vseh gospodarskih središčih že prevladujejo storitve (trgovina, strokovne storitve, prometne, logistične ...). Nastala so tudi nekatera popolnoma nova središča, na primer v delu Rudnika in Tehnološkega parka na Brdu. V obeh navedenih primerih gre načrtno širjenje, medtem ko je zlasti ob nekaterih mestnih vpadnicah vidno bolj »spontano « širjenje določenih gospodarskih dejavnosti, zlasti obrtniških in manjših podjetniških (Tržaška cesta), ki pa je po površini precej manjše.

O širjenju obstoječih ali popolnoma novih gospodarskih območij smo sklepali na podlagi predloga Izvedbenega prostorskega načrta MOL, ki je nastal v letu 2008 ter je bil med pripravo in oddajo prispevka edini aktualni (novi, dopolnjeni osnutek IPN MOL je bil objavljen konec leta 2009, ko je bil prispevek že poslan v recenzentski postopek). Na podlagi tega predloga poskušamo ovrednotiti, katera gospodarska središča se bodo predvidoma povečala in katera zmanjšala.

Ob predvidevanju, da dejanski prostorski načrt ne bo bistveno odstopal od predloga IPN MOL (2008), se bodo v Ljubljani gospodarske razmere bistveno spremenile. Spremembe se pričakujejo v teh segmentih:

- prostorsko širjenje in krčenje določenih gospodarskih območij in popolnoma nov (greenfield) razvoj gospodarskih območij;

- spreminjanje funkcije in notranje zgradbe sekundarnih gospodarskih središč.

\subsection{Prostorsko širjenje/krčenje in nov (greenfield) razvoj}

Ob pregledu predloga IPN MOL smo izločili štiri temeljne skupine načrtovanega razvoja gospodarskih območij v MOL:

- V prvo skupino so uvrščena večja povečanja (nad 20 hektarjev) obstoječih gospodarskih območjih, ki bodo predvidoma obsegala 159 hektarjev. Gre za povečanje nekaterih industrijskih središč (Črnuče, Zalog in Vevče).

- V drugo skupino so vključena manjša povečanja (pod 20 hektarjev) ali dozidave obstoječih gospodarskih območjih, ki bodo predvidoma obsegale 33 hektarjev. Predvsem gre za tista gospodarska središča, ki so še vedno v fazi gradnje, na primer Tehnološki park Brdo ali Nakupovalno središče Rudnik.

- V tretjo skupino so umeščna popolnoma na novo načrtovana samostojna gospodarska območja (razvoj greenfield), ki bodo po predlogu IPN MOL obsegala 88 hektarjev. Gre za območje pri Nadgorici, zaradi nameravane trgovske funkcije pa smo vključili tudi Stožice, v katerih naj bi do leta 2011 nastalo novo trgovsko središče.

- V 4. skupino smo vključili območje linearnega razvoja gospodarskih dejavnosti ob Tržaški cesti. IPN MOL namreč ureja to gospodarsko območje stihijsko ter namerava različne obrtne in manjše podjetniške dejavnosti ob tej vpadnici zaokrožiti in dopolniti v enotnejšo morfološko obliko. $\mathrm{Z}$ dograditvami » praznih « prostorov bo to ob- 


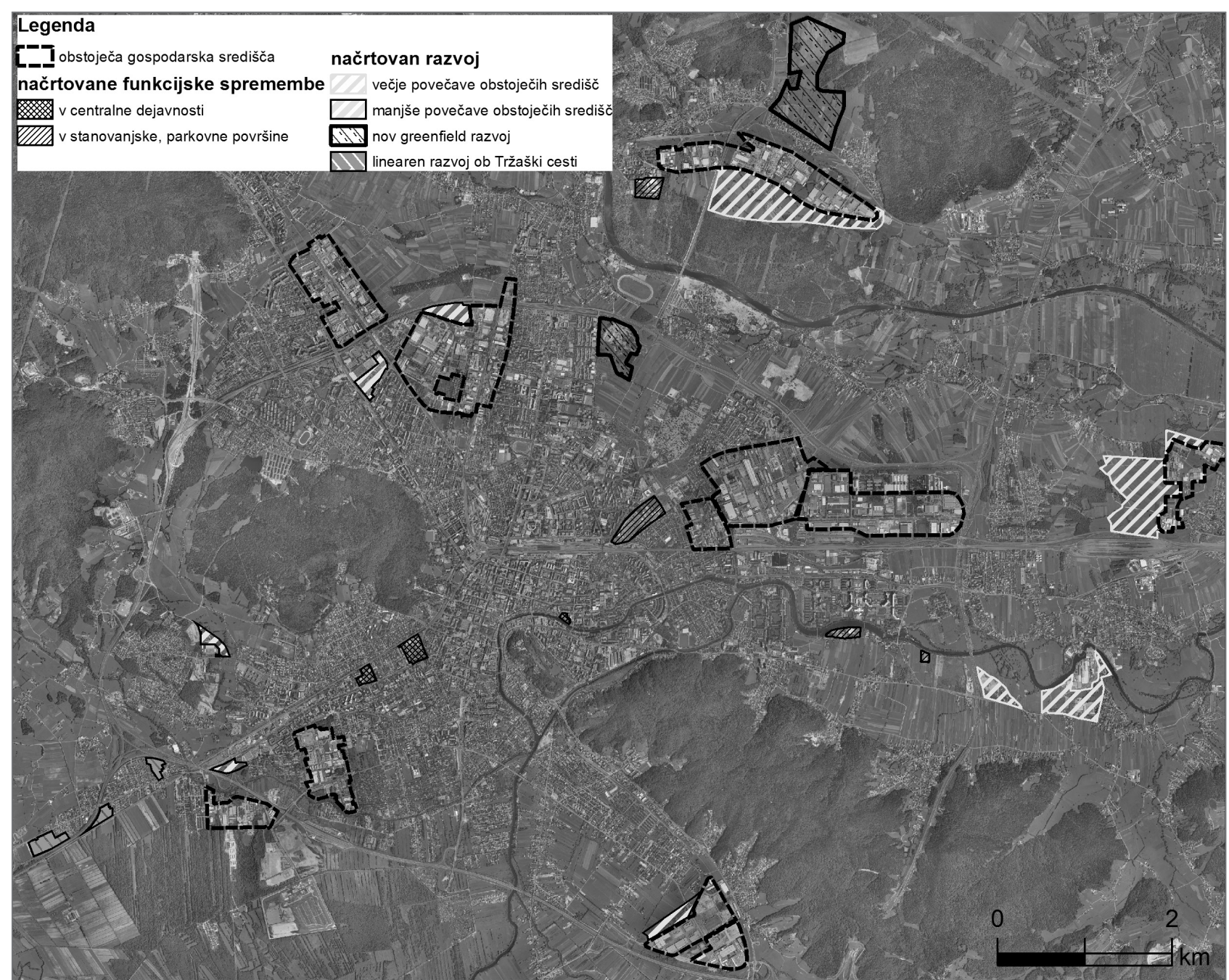

Slika 8: Načrtovan prostorski razvoj gospodarskih območij v Ljubljani glede na IPN MOL (Mestna občina Ljubljana, 2008)

močje postalo pomembnejše, saj vključuje še dodatnih 13 hektarjev novih površin za gospodarske dejavnosti, zlasti pisarniške in podjetniške.

Skupaj je v IPN MOL 2008 za nadaljnji razvoj načrtovanih 268 hektarjev površin na že obstoječih in na popolnoma novih sekundarnih gospodarskih območjih v Ljubljani (slika 8). Največji delež načrtovanega širjenja gospodarskih con imajo obstoječa industrijska območja, na katerih naj bi se dogajala največja povečanja. V sekundarnem poslovnem območju Črnuč je razširitev predvidena južno od obstoječe pozidave. Po predlogu IPN 2008 bo ta novi del gospodarske cone obsegal še dodatnih 58 hektarjev. $S$ tem bo to območje postalo po površini največje gospodarsko območje v Ljubljani in hkrati tudi največje industrijsko območje. Skoraj enako velika razširitev zahodno od že pozidanih površin je predvidena $\mathrm{v}$ gospodarskem središču Zalog (prometno-logistični terminal), ki bo tako postalo drugo največje gospodarsko središče za Črnučami. Obe gospodarski območji se bosta povečali na račun kmetijskoobdelovalnih površin.
Manjša povečanja so predvidena na območju Nakupovalnega središča Rudnik in ob Tržaški cesti (Avtoline). V bližini Tehnološkega parka je predvidena naslednja faza gradnje, ki bo obstoječe pisarniško območje razširila za dodatnih 5 hektarjev. Prav tako naj bi se nekoliko povečala industrijska cona v Šiški, in sicer naj bi se na severu kmetijske površine zapolnile vse do obvoznice.

Med posameznimi načrtovanimi gospodarskimi območji bo največja sprememba $(67,8 \mathrm{ha})$ novo gospodarsko središče, ki se naj bi nastalo severno od obstoječega sekundarnega poslovnega območja Črnuče pri Nadgorici. Po aktualnem stanju je to območje še kmetijsko zemljišče. Po predlogu IPN MOL bo to industrijska cona, za katero se predvideva, da bo konkurenčna bližnji trzinski gospodarski coni.

V Stožicah je predvideno novo gospodarsko območje, na katerem naj bi se razen novega športnega stadiona (trenutno $\mathrm{v}$ izgradnji) razvila tudi trgovska funkcija. To dejstvo v predlogu IPN MOL ni jasno označeno, saj je območje označeno kot 


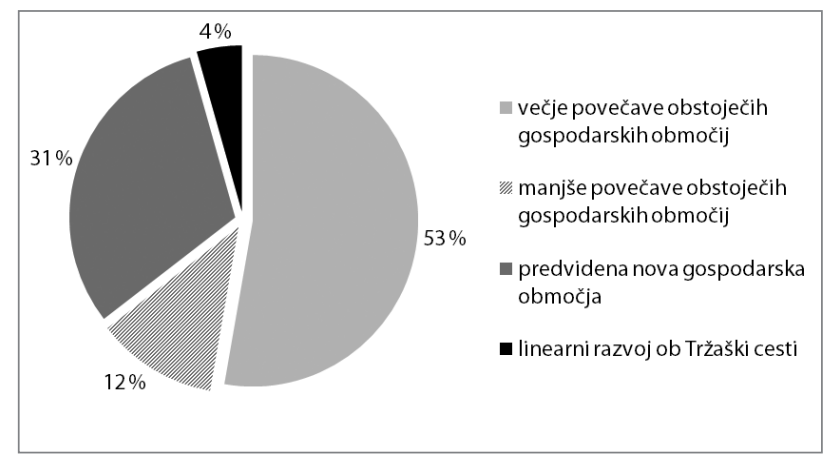

Slika 9: Deleži načrtovanega širjenja obstoječih in novih gospodarskih območjih v Ljubljani (Mestna občina Ljubljana, 2008)

površina za športni center (oznaka BC). Trgovska funkcija območja naj bi bila poudarjena po zaslugi trgovskega objekta, ki naj bi obsegal 20 hektarjev površin in poleg večjega hipermarketa združeval še večje število manjših trgovin.

Poleg širjenja bo na podlagi osnutka IPN MOL potekalo tudi manjšanje gospodarskih površin. Zlasti v starejših, predvojnih industrijskih območjih, ki imajo že sedaj spremenjeno funkcijo in so z vidika lokacije primernejša za stanovanjsko ali storitveno funkcijo. V stanovanjske ali centralne površine se bodo najbrž spremenila območja tovarne Kolinska, deloma tudi Tobačne, Ilirije in Roga. V Osnutku IPN MOL pa se načrtujejo tudi druge spremembe: območji tovarn Žima in Totra naj bi se preoblikovali v posebna stanovanjska območja in parkovne površine, delu kmetijske farme v Sneberjah pa naj bi se spremenila namembnost, uporabljal naj bi se v turistične namene (oznaka BT). V stanovanjsko območje naj bi se spremenilo tudi manjše območje tovarne Elma v Črnučah.

\subsection{Funkcijska preobrazba sekundarnih gospodarskih središč}

Omeniti pa ni treba le prostorskih sprememb, pozornost je treba nameniti tudi funkcijskim spremembam znotraj gospodarskih središč in njihovemu krčenju. Da je deindustrializacija in hkratna terciarizacija prevladujoč proces v Ljubljani, potrjuje tudi dejstvo, da se ostala storitvena gospodarska središča

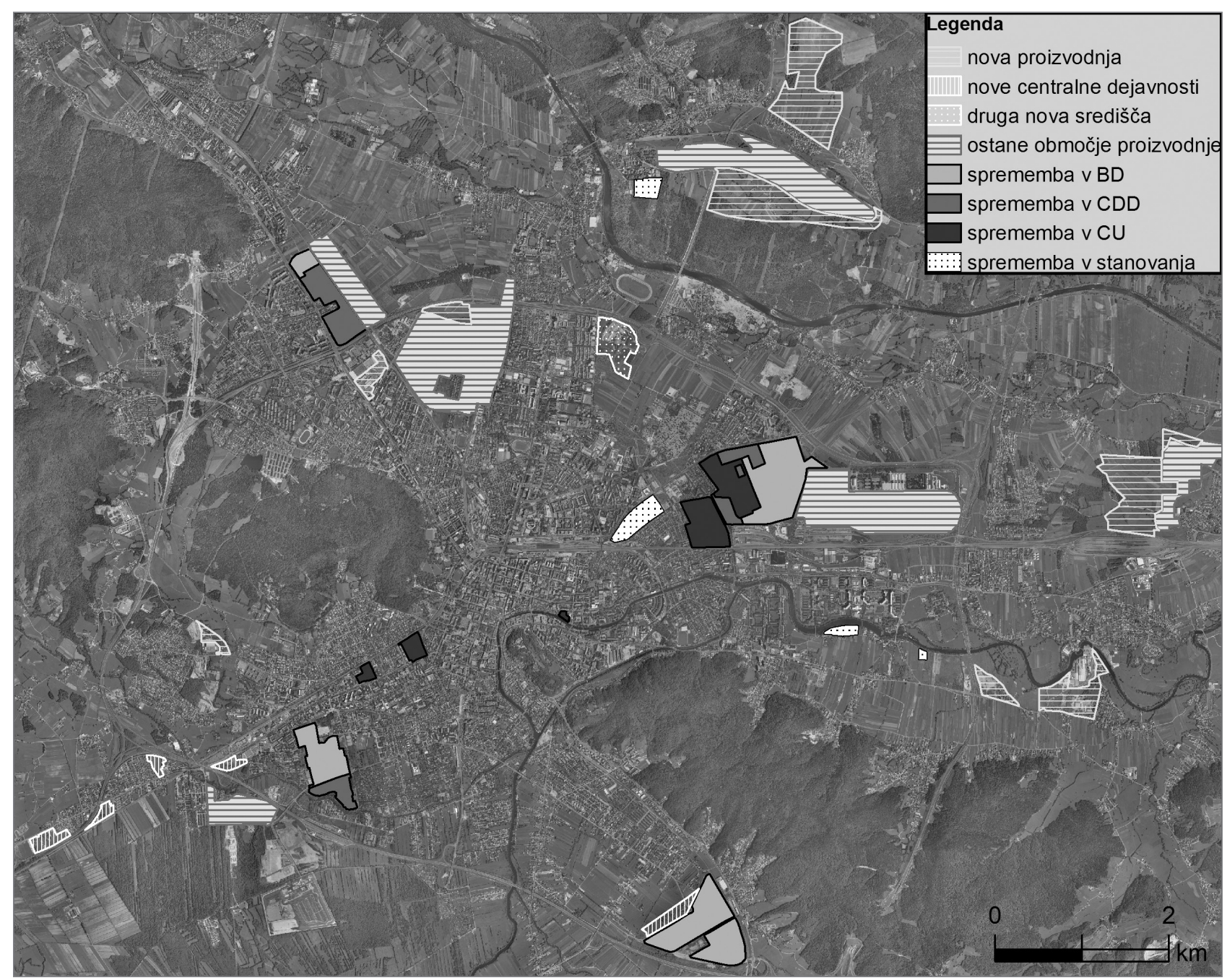

Slika 10: Načrtovani funkcijski razvoj gospodarskih območij v Ljubljani glede na IPN MOL (Mestna občina Ljubljana, 2008) 
ne bodo zmanjševala, ampak se bodo le notranje preobražala. Največje trgovsko območje BTC naj bi se tako ločilo na več delov, na severni, bolj »poslovni « del in južni del, ki naj bi ohranil prevladujočo oskrbno funkcijo. Širjenje BTC je predvideno s spremembo namembnosti tovarne Žito in z manjšim širjenjem na severovzhodnem delu, proti obvoznici, kjer naj bi pridobili površine za mirujoči promet. Maja 2008 je bil izveden tudi natečaj za ureditev območja ob Šmartinski cesti, ki deloma nakazuje težnje prihodnjega razvoja tega območja. V vseh izbranih projektih se namreč poudarjajo zgoščena gradnja, gradnja višjih stolpnic in »oživljanje « tega območja z navezovanjem na mestno jedro ter ustvarjanjem parkovnih površin in pešcem prijaznejših območij. Predvideni so tudi drugi projekti, ki lahko temeljito spremenijo podobo mesta. Mednje spadajo gradnja potniškega centra ob glavni železniški in avtobusni postaji, ureditev območja ob Bavarskem dvoru, Novi Kolizej ...

Iz karte funkcijskih sprememb v osnutku IPN MOL je razvidno, da bodo industrijsko funkcijo ohranila le še območja v Šiški, delu Stegen, Črnučah in ob Cesti dveh cesarjev. Večina ostalih območij se bo tudi formalno preobrazila v nakupovalno-oskrbna območja (Rudnik, BTC, Vič ...) oziroma območja z mešano centralno ali izključno centralno dejavnostjo brez stanovanjskih površin. Površine, namenjene proizvodnji, se bodo zmanjšale na 630 hektarjev, kar je sicer za polovico manj kot $\mathrm{v}$ obstoječem prostorskem planu, vendar pa bo od tega skoraj 240 hektarjev popolnoma novih povečanj greenfield. V preglednici 3 je mogoče videti, da v predlogu IPN MOL prevladuje preobrazba gospodarskih središc iz proizvodne v storitveno funkcijo. Največja preobrazba bo sprememba iz proizvodne namenske rabe $\mathrm{v}$ centralne dejavnosti. To velja zlasti za tista gospodarska središča, ki že dolgo nimajo proizvodne funkcije, ampak samo oskrbno in storitveno.

Preglednica 3: Načrtovane funkcijske spremembe sekundarnih gospodarskih središč v predlogu IPN MOL

\begin{tabular}{|c|c|}
\hline Opis spremembe & Površina (ha) \\
\hline ostane proizvodna funkcija (gospodarske cone) & 391,43 \\
\hline nove proizvodne gospodarske cone & 239,59 \\
\hline $\begin{array}{l}\text { sprememba iz proizvodne dejavnosti v centralne } \\
\text { dejavnosti }\end{array}$ & 139,10 \\
\hline $\begin{array}{l}\text { sprememba iz proizvodne dejavnosti v centralne } \\
\text { dejavnosti brez stanovanj }\end{array}$ & 53,01 \\
\hline nova območja centralnih dejavnosti & 24,38 \\
\hline $\begin{array}{l}\text { sprememba iz proizvodne dejavnosti v osrednje } \\
\text { centralne dejavnosti }\end{array}$ & 57,71 \\
\hline $\begin{array}{l}\text { sprememba iz proizvodne dejavnosti v stano- } \\
\text { vanjsko dejavnost }\end{array}$ & 25,51 \\
\hline druga nova gospodarska območja & 20,63 \\
\hline
\end{tabular}

Vir: Bole in Ravbar (2009)

Nakupovalna središča se bodo obdržala in nekoliko povečala na območjih BTC, Rudnik, Vič, Mercator Šiška. Drugod se bo industrijska namembnost $\mathrm{v}$ prostorskem načrtu spremenila v centralne dejavnosti. Območja v Stegnah, Zeleni jami, ob Šmartinski cesti v BTC in v južnem delu Viča bodo namenjena pisarniškim in drugim komercialnim dejavnostim brez stanovanj, na drugih območjih pa se bodo prepletale trgovske in bivalne funkcije (oznaka CU).

Prostorske in funkcijske spremembe gospodarskih središč v prihodnje lahko glede na IPN MOL 2008 označimo tako:

- Industrijska (proizvodna) območja se bodo celostno gledano skrčila, zlasti se bo načrtovano stanje prilagodilo trenutno obstoječemu. Ohranil se bo le manjši del industrijskih gospodarskih con, več kot ena tretjina novih površin pa bo nastala popolnoma na novo.

- Izginila oziroma preoblikovala se bodo nekatera trenutno popolnoma industrijska območja: Ilirija, Totra, Žima in nekatera druga; večinoma v komercialno, deloma tudi v stanovanjsko in drugo namembnost.

- V vseh ostalih pogledih se bo novi predlog IPN MOL le prilagodil novemu stanju: to velja za območja nakupovalnih središč in tudi centralnih dejavnosti.

- Edina neindustrijska investicija greenfield je predvidena ob Tržaški cesti, deloma pa tudi v Stožicah z nakupovalnim središčem in $s$ športnim stadionom.

Očitno je, da se bodo gospodarska središča v prihodnje prostorsko razširila, zlasti na račun novih industrijskih območij. Še izraziteǰse pa bodo funkciiske spremembe gospodarskih središč, vendar bolj z vidika ažuriranja/poenotenja prostorskega načrta $\mathrm{z}$ dejanskim stanjem kot $\mathrm{z}$ vidika stvarne funkcijske preobrazbe.

\section{Kritična presoja predloga izvedbenega prostorskega načrta MOL}

Presoja temelji na grafičnih prilogah zadnje verzije IPN MOL iz leta 2008, zato lahko podamo le mnenje na ta predlog. Delno se presoja navezuje tudi na rezultate analize poslovnih subjektov v središčih (glej poglavje 3.6), upoštevali pa smo tudi merila, ki so širše obrazložena v ostalih publikacijah (Plut, 2006; Bole, 2008b; Bole in Ravbar, 2009):

- razvoj greenfield $\mathrm{v}$ gospodarskih središcih je z vidika sonaravnosti manj zaželen;

- funkcijska zgradba gospodarskih središč mora ustrezati dejanskim potrebam v prostoru (manj klasične delovne intenzivne industrije, več storitev in visokotehnološke proizvodnje in prilagajanje dejanskemu stanju);

- enostranska specializacija znotraj gospodarskih središč ni zaželena, priporočeno je logično prepletanje sorodnih dejavnosti; 
- z vidika uravnoteženega razvoja mestne regije naj se namesto prevelike konkurenčnosti sekundarnih središč spodbuja njihova medsebojna komplementarnost;

- središča naj se poskušajo infrastrukturno čim bolj navezati na mesto oziroma se »urbanizirati $\ll$;

- središča naj bodo dobro povezana $\mathrm{z}$ javnim potniškim prometom;

- $\mathrm{z}$ vidika bolj smiselne rabe prostora in infrastrukture je zaželen koridorski princip oblikovanja gospodarskih središč.

Večinoma predlog IPN MOL sicer upošteva zgoraj navedena merila presoje, kritično pa lahko izpostavimo zlasti preveč poudarjen razvoj greenfield in manj primerno funkcijsko strukturo nekaterih območij. Nekatera povečanja greenfield na proizvodnih območjih se ne zdijo popolnoma smiselna. Sekundarno središč v Črnučah naj bi se tako precej povečalo na račun zelenih površin, hkrati pa naj bi se del že pozidanega območja okoli tovarne Elma namenil stanovanjski rabi. Ker pa obstoječe gospodarske dejavnosti na tem območju že sedaj ne uspevajo, je širjenje na kmetijske površine v neposredno bližino vodovarstvenega območja manj smiselno. Podobno ugotavljamo za središči v Zalogu in Vevčah.

Z ekonomskogeografskega vidika je najspornejše širjenje novih industrijskih gospodarskih con. Kazalniki o funkcijskih spremembah znotraj MOL (Bole, 2008b) potrjujejo močno težnjo terciarizacije in deindustrializacije Ljubljane. V predlogu IPN MOL pa se načrtuje 240 hektarjev območij greenfield z oznako IG, kar označuje tehnološke, industrijske, proizvodne objekte $s$ spremljajočimi storitvami (na primer trgovinami do 2.000 $\mathrm{m}^{2}$ ). Čeprav se bodo težnje po deindustrializaciji v Ljubljani zmanjšale ali celo ustavile, so predvidene površine v IPN MOL obsežne - še posebej če upoštevamo, da postfordistična organizacija dela v industriji zahteva večjo udeležbo specializiranih storitvenih dejavnosti (raziskave in razvoj, trženje), ki praviloma potrebujejo manj prostora kot klasična industrijska proizvodnja. Pred širjenjem bi bila potrebna tudi temeljitejša analiza industrijske funkcije v Ljubljani. Za gospodarske cone je v IPN MOL namenjenih 630 hektarjev območij, kar ustreza tudi okoljsko naravnanem scenariju razvoja industrije, ki sta ga opravila Damjan Kavaš and Klemen Koman (2007). Vendar je več kot tretjina te površina predvidena na novih nepozidanih zemljiščih (kmetijskih, gozdnih površinah).

Kljub vsemu so na določenih gospodarskih območjih pomembni industrijski obrati, v okviru katerih bo namenska raba tal drugačna od proizvodne. Analiza gospodarskega središča na Viču potrjuje, da tam obstaja zgostitev podjetij plastične industrije, močno proizvodno funkcijo pa ima tudi južni del omenjenega območja. V konkretnem primeru je grozd plastič- ne industrije v predlogu IPN MOL znotraj oznake BD, ki ne dopušča industrijske ali proizvodne dejavnosti oziroma dovoljuje le rekonstrukcijo objektov. Zdi se da je predlog IPN MOL $\mathrm{v}$ določenih primerih prestrog in nagnjen $\mathrm{k}$ preveč izraziti specializaciji določenih gospodarskih središč niti ne predvideva soodvisnosti in koristnosti mešanja različnih gospodarkkih funkcij - to, kar se je spontano že zgodilo v večini gospodarskih središč in kar potrjujejo tudi izsledki analize (glej poglavje 3.2).

Gospodarska središča, ki se ne dopolnjujejo, temveč konkurirajo znotraj iste mestne regije, z vidika uravnoteženega razvoja celotne regije niso primerna. Zato se postavlja resno vprašanje o smiselnosti vzpostavljanja obrtne cone v Nadgorici, ki bi bila po programski strukturi identična trzinski gospodarski coni in bi bila hkrati le nekaj sto metrov oddaljena od nje. Gospodarsko središče v Nadgorici bi hkrati konkuriralo tudi obstoječemu in predvideno povečanemu središču v Črnučah, ki naj bi imelo podobno programsko strukturo. Ali je takšna zgostitev sorodnih gospodarskih središč smiselna in ali bi take cone dejansko zaživele, je zato smiselno vprašanje.

Javni potniški promet ima sicer pomembno vlogo v strateškem delu predloga prostorskega načrta MOL (Mestna občina Ljubljana, 2009). IPN MOL razkriva, da nekatera načrtovana gospodarska središča niso zadovoljivo povezana z javnim potniškim prometom. Glede na dejstvo, da imajo sekundarna gospodarska središča vse več delovnih mest in tudi druge funkcije, mora biti povezava z javnim prometom zelo kakovostna in ne le ustrezati »minimalnemu standardu «, če želimo ustaviti težnje naraščanja osebnega motoriziranega prometa. Skladno načrtovanje rabe zemljišč in javnega prometa je zato potrebno v izvedbenem delu prostorskega načrta. Predlog IPN MOL ponekod ne izboljšuje bistveno povezav sedanjih in prihodnjih gospodarskih središč z javnim potniškim prometom, ampak le ohranja trenutno stanje.

Usmerjanje gospodarskih središč znotraj določenih razvojnih koridorjev je smiselno z vidika kanaliziranja prometnih tokov in infrastrukturne opremljenosti. Razvojni koridorji so deloma začrtani že v strateškem delu prostorskega načrta, IPN MOL pa večinoma upošteva lokacije znotraj razvojnih osi Ljubljane. Sporna so lahko le izolirana območja gospodarskih dejavnosti, ki nastajajo zunaj koridorjev - na primer Tehnološki park Brdo in druga gospodarska območja, ki so po velikosti manj pomembna.

Na podlagi omenjenih meril lahko identificiramo predlagana gospodarska središča v IPN MOL, ki so manj ustrezna. Za šest sekundarnih gospodarskih središč, ki najbolj očitno ne ustrezajo postavljenim merilom pa je smiselna ponovna presoja lokacij ali pa spremembe in dopolnitve IPN MOL. 
Preglednica 4: Sekundarna gospodarska središča v predlogu IPN MOL, ki najmanj ustrezajo postavljenim merilom.

\begin{tabular}{|c|c|c|c|}
\hline Oznaka v IPN MOL & Ime & Oznake rabe & Neupoštevanje meril \\
\hline ČR-377 & $\begin{array}{l}\text { Poslovna cona } \\
\text { Nadgorica }\end{array}$ & IG & $\begin{array}{l}\text { - obsežen razvoj greenfield; } \\
\text { - neuravnotežena konkurenčnost (bližina trzinske cone); } \\
\text { - navezanost na mesto (oddaljenost od mesta in prostorska »izločenost«); }\end{array}$ \\
\hline ČR-155 & Brnčičeva - jug & IG & $\begin{array}{l}\text { - obsežen razvoj greenfield; } \\
\text { - neuravnotežena konkurenčnost (bližina programsko sorodne cone v } \\
\text { Nadgorici in Trzinu); } \\
\text { - problem funkcijske zgradbe (območje je trenutno funkcijsko drugačno } \\
\text { od načrtovanega v IPN); }\end{array}$ \\
\hline PO-375 & $\begin{array}{l}\text { Prometno logi- } \\
\text { stični terminal } \\
\text { Zalog }\end{array}$ & IG & $\begin{array}{l}\text { - obsežen razvoj greenfield; } \\
\text { - javni promet (v IPN MOL ni predvidene povezave z javnim prometom); }\end{array}$ \\
\hline SO-1405 & Papirnica Vevče & IG & $\begin{array}{l}\text { - obsežen razvoj greenfield; } \\
\text { - problem funkcijske zgradbe (v predlogu IPN MOL ni določena natančna } \\
\text { funkcija, potrebe po industrijskih površinah v MOL niso velike); }\end{array}$ \\
\hline VI-211 & Obrtna cona Vič & BD & $\begin{array}{l}\text { - problem funkcijske zgradbe (trenutno locirana nekatera inovativna } \\
\text { industrijska in obrtna podjetja, ki po predlogu IPN MOL industrijske } \\
\text { dejavnosti ne bodo smela širiti); } \\
\text { - javni promet (v predlogu IPN ni načrtovana bistveno izboljšana poveza- } \\
\text { va z javnim prometom); }\end{array}$ \\
\hline DR-374 & Stegne & IG & $\begin{array}{l}\text { problem funkcijske zgradbe (gre za eno pomembnejših storitvenih } \\
\text { gospodarskih območij v Ljubljani in središče veleprodajne dejavnosti } \\
\text { (Bole 2008b), ki ne ustreza popolnoma namenski rabi območij z oznako } \\
\text { »G«, v okviru katerih imajo prednost proizvodne površine, storitvene } \\
\text { pa so le »dopolnilne«). }\end{array}$ \\
\hline
\end{tabular}

Vir: Bole in Ravbar (2009)

\section{Sklep}

Sekundarna gospodarska središča so gotovo ena najvidnejših značilnosti mesta. Enako velja tudi za Ljubljano, v kateri se raztezajo na skoraj 1.000 hektarjev površin, na katerih je skoraj $40 \%$ vseh podjetij v občini in ki poosebljajo novo, postindustrijsko podobo mesta. Ta središča lahko ločimo na podlagi njihovega zgodovinskega razvoja, ki se pogosto kaže tudi v njihovi gospodarski strukturi in funkciji, ki jo imajo v mestnem prostoru. S tem prispevkom smo prikazali mogočo tipizacijo sekundarnih gospodarskih središč, njihovo gospodarsko strukturo in vlogo v občini. Za vsako središče lahko na podlagi strukture poslovnih subjektov ugotovimo njegovo funkcijo. Še posebej izrazita je oskrbna (trgovska) funkcija teh območij, medtem ko proizvodna funkcija očitno zamira.

Omenili smo tudi nekatera pomembna vprašanja, ki se nanašajo na prostorski razvoj novejših gospodarskih območij znotraj Mestne občine Ljubljana. Ta vprašanja in pomisleki so lahko osnova za ponovni razmislek o smiselnosti posameznih lokacij gospodarskih središč. Pri tem poudarjamo, da je nujno enotno gledanje na razvoj sekundarnih središč, podobno kot na mestno središče. S samo sektorskim pogledom lahko namreč spre- gledamo njihovo funkcionalno prepletenost, kar lahko vodi v zgrešene načrtovalske posege in zato negativno vpliva na širši gospodarski razvoj mesta. Na strateški ravni pa je potrebna tudi dokončna odločitev o tem, katere gospodarske panoge so najbolj zaželene v občini, tako z vidika nadaljnjega razvoja kot z vidika globalne konkurenčnosti. Šele jasna vizija gospodarskega in širšega družbenega razvoja je lahko podlaga za pravilno umeščanje sodobnih gospodarskih središč v Ljubljani.

Manjka tudi regionalni vidik umeščanja gospodarskih središčc, njihove usklajenosti in prostorske uravnoteženosti. Del gospodarskih dejavnosti bi lahko prevzele tudi druge občine $\mathrm{v}$ regiji, kar bi nudilo obojestransko korist Ljubljani in okoliškim občinam. Vendar trenutni razvoj poudarja nastajanje številnih manjših lokalnih (»občinskih «) gospodarskih središč, ki si medsebojno konkurirajo ter prostorsko in funkcionalno niso smiselno povezana.

\section{David Bole}

Geografski inštitut Antona Melika Znanstvenoraziskovalnega centra Slovenske akademije znanosti in umetnosti, Ljubljana, Slovenija E-pošta: david.bole@zrc-sazu.si 


\section{Zahvala}

Prispevek je rezultat raziskovalnega projekta Analiza sodobnih poslovnih, nakupovalnih in drugih gospodarskih središč v Ljubljani, ki smo ga pripravili sodelavci Geografskega inštituta Antona Melika ZRC SAZU. Za financiranje se zahvaljujemo Mestni občini Ljubljana.

\section{Viri in literatura}

Agencija Republike Slovenije za javnopravne evidence in storitve (2009): Poslovni register Slovenije. Ljubljana.

Berry, B. J. L. (1963): Commercial structure and commercial blight. Chicago, University of Chicago.

Berry, B. J. L., in Horton, F. E. (1970): Geographic perspectives on urban systems. New Jersey, Prentice-Hall.

Bole, D. (2008a): Cultural industry as a result of new city tertiarization. Acta geographica Slovenica/Geografski zbornik, 48(2), str. 255-276.

Bole, D. (2008b): Ekonomska preobrazba slovenskih mest. Ljubljana, Geografski inštitut Antona Melika ZRC SAZU.

Bole, D., in Ravbar, M. (2009): Analiza sodobnih poslovnih, nakupovalnih in drugih gospodarskih središč v Ljubljani. Elaborat. Ljubljana, Geografski inštitut Antona Melika ZRC SAZU.

Bontje, M., in Burdack, J. (2005): Economic poles in the European metropolitan periphery and sustainable development. Leipzig. Forum IFL.

Carol, H. (1960): The hierarchy of central functions within the city. Annals of Association of American Geographers, 50(4). str. 419-438.

Carter, H. (1972): The study of urban geography. London, Edward Arnold.

Čok, G. (2003): Gospodarske cone: vsebinska in terminološka opredelitev. Urbani izziv, 14(1), str. 55-59.

Dolgoročni plan občin in mesta Ljubljane za obdobje 1986-2000 za območje Mestne občine Ljubljana. Uradni list Socialistične Republike Slovenije št. 11/1986 in spremembe. Ljubljana.

Filipič, B. (2000): Poslovne cone. V: Glas, M., in Pšeničny, V. (ur): Podjetništvo - izziv 21. stoletja. Ljubljana, Ministrstvo za malo gospodarstvo in turizem.

Genorio, R. (1978): Geografija poslovnega središča v Ljubljani. Diplomska naloga. Ljubljana, Univerza v Ljubljani, Filozofska fakulteta, Oddelek za geografijo.

Gulič, A., in Mladenovič, L. (2009): Gospodarske cone v Ljubljanski urbani regiji. Gradivo za delavnico Strokovne podlage za pripravo regionalnega prostorskega načrta LUR. Ljubljana, Urbanistični inštitut RS.

Hall, P. (1997): Modelling the post-industrial city. Futures, 29(4-5), str. 311-322.

Johnston, R., J. (1971): Urban residental patterns: An introductory review. London, Bell \& Sons.

Kavaš, D., in Koman, K. (2007): Analiza gospodarstva v MOL. Priloga 6 osnutka strateškega prostorskega načrta Mestne občine Ljubljana. Ljubljana, Inštitut za ekonomska raziskovanja.
Lang, R., Sanchez, T., in LeFurgy, J. (2006): Beyond edgeless cities: Office geography in the new metropolis. Dostopno na: http://www. mi.vt.edu/uploads/Edgeless\%20Cities.pdf (sneto 1. 7. 2007).

Mestna občina Ljubljana (2008): Izvedbeni prostorski načrt Mestne občine Ljubljana. Dostopno na: http://urbanizem.ljubljana.si/index. $\mathrm{htm}$ (sneto 1. 12. 2008).

Mestna občina Ljubljana (2009): Strateški prostorski načrt Mestne občine Ljubljana - dopolnjeni osnutek. Dostopno na: https:// urbanizem.ljubljana.si/index2/SPN.htm (sneto 26. 1. 2009).

Pacione, M. (2001): Urban geography - a global perspective. London, New York, Routledge.

Pak, M. (2000): Funkcijska zgradba. V: Gabrovec, M., in Orožen Adamič, M. (ur.): Ljubljana - geografija mesta. Ljubljana, Ljubljansko geografsko društvo.

Pak, M., in Rus, A. (2005): Problematika razvoja mest in spreminjanja rabe mestnega prostora. Dela, 24, str. 159-170.

Plut, D. (2006): Mesta in sonaravni razvoj. Ljubljana, Znanstvenoraziskovalni inštitut Filozofske fakultete Univerze v Ljubljani.

Prostorski red Slovenije. Uradni list Republike Slovenije, št. 60/2004. Ljubljana.

Ravbar, M. (2005): „Urban Sprawl«: popačena slika (sub)urbanizacije v Sloveniji? Geografski vestnik, 77(1), str. 27-36.

Rebernik, D. (2000): Morfološka zgradba. V: Gabrovec, M., in Orožen Adamič, M. (ur.): Ljubljana - geografija mesta. Ljubljana, Ljubljansko geografsko društvo.

Sieverts, T. (2003): Cities without cities. London, Spon Press.

Soja, E. (2000): Postmetropolis: Critical studies of cities and regions. Oxford, Blackwell.

Stanilov, K. (2007): The postsocialist city: Urban form and space transformations in central and eastern Europe after socialism. London, Springer.

Tosics, I. (2005): City development in Central and Eastern Europe since 1990: The impacts of internal forces. V: Hamilton, I., Dimitrovska Andrews, K., in Pichler Milanović, N. (ur.): Transformation of cities in Central and Eastern Europe, str. 131-150. New York, United Nations University Press. 